Assiut University web-site: $\underline{w w w . a u n} . e d u . e g$

\title{
EFFECT OF IRRADIATION AND NATAMYCIN ON DECONTAMINATION OF FUNGI FROM LABORATORY INOCULATED MINCED MEAT
}

\author{
DOAA A.H. EL-MATARY ${ }^{1}$ WEAM M. BAHER ${ }^{2}$ and NASHOWA M. ZAKI ${ }^{2}$ \\ ${ }^{1}$ Unit of Mycology, Animal Health Research Institute, Dokki, Gizza, El Mansoura Provincial Laboratory \\ ${ }^{2}$ Unit of Food Control, Animal Health Research Institute, Dokki, Gizza, El Mansoura Provincial Laboratory
}

Received: 31 December 2016;

Accepted: 31 January 2017

\begin{abstract}
This study was carried out on 60 samples of fresh minced meat $(200 \mathrm{~g})$ for each to evaluate the effect of both gamma irradiation and $0.1 \%$ natamycin on elimination of total mould and yeast count. Samples were divided into 5 groups (12 for each), all samples were sterilized by using gamma irradiation at dose $10 \mathrm{kGy}$ then artificially inoculated with Candida albicans and Aspergillus niger at infected dose $10^{5} \mathrm{cfu} / \mathrm{g}, 1^{\text {st }}$ group not treated (control), $2^{\text {nd }}, 3^{\text {rd }}$, and $4^{\text {th }}$ groups were exposed to gamma irradiation at doses of $(2.5,4.0,6.0 \mathrm{kGy})$ respectively. While $5^{\text {th }}$ group treated with $0.1 \%$ natamycin by spraying. All samples chilled at $\left(4^{\circ} \mathrm{C}\right)$ for 15 days. Total mould and yeast count were detected at zero, 5, 10, 15 days of storage. The results showed that there was a significant difference between non-irradiated (control) samples and irradiated samples at (2.5, 0.4, 0.6 kGy) at zero, 5 and 10 days of storage and there was a significant difference between doses of 4.0 and $6.0 \mathrm{kGy}$ at 15 days of storage as the control samples were spoiled, the samples exposed to $6.0 \mathrm{kGy}$ were contained less mould and yeast growth than that exposed to $4.0 \mathrm{kGy}$ irradiated dose. Samples treated with natamycin $0.1 \%$ showed a significant decrease in total mould and yeast count in comparison with untreated (control) group at 5, 10 days of storage day. As well as there was significant differences between treated samples at 15 days of storage and each treated samples at 5 and 10 days of storage.
\end{abstract}

Key Words: Irradiation, Natamycin, Decontamination, Fungi, Minced Meat.

\section{INTRODUCTION}

Meat is a source of animal protein which contains all essential amino acids required for human nutrition. Contamination of meat and meat products by fungi originated from different sources as additives spices (Farkasm, 1989), contamination by food handlers (Soriano et al., 2000), from water, processing environment and microbial fecal contamination (Seri and Mohd, 2006 and Thalita et al., 2014). A wide spectrum of filamentous fungi and yeasts is often found in various food commodities, where they can cause extensive damage and lead to sizable economic loss. Fungal infection leads to meat spoilage such as off-flavors, discoloration, rotting and disintegration of the food structure. The very important aspect involved in spoilage of food by fungi is also the formation of toxic secondary metabolites - mycotoxins which produced by some filamentous fungi. Concerning the importance and diversity of their toxic effects carcinogenic, teratogenic, mutagenic, immunotoxic, neurotoxic,

Corresponding author: Dr. DOAA A.H. EL-MATARY

E-mail address: doaaelmatary@yahoo.com

Present address: Unit of Mycology, Animal Health Research Institute, Dokki, Gizza, El Mansoura Provincial Laboratory nephrotoxic and hepatotoxic, the occurrence of mycotoxinogenic moulds in foods constitutes a high risk for human and animal health (Sirion, et al., 2005, Anandarja et al., 2006 and Ma et al., 2011, Singh et al., 2012, Dahama et al., 2013 and Nurzhan, 2015). Although prevention of fungal growth and mycotoxins production in feedstuffs is usually considered as the best approach to impede the harmful effects on animal and human health, decontamination and detoxification of contaminated products is also of prime importance (Varga et al., 2005). Several physical and chemical techniques are used for the preservation of meat and meat products. Drying, freeze, cold storage, modified atmosphere storage and heat treatments are all means of physical methods of food preservation. Several chemical additives also are used as preservatives, and those are organic acids - acetic, lactic, sorbic, benzoic and propionic, as well as some antibiotic, such as natamycin. Consumers required high quality meat that has fresh appearance with natural flavor and taste. Therefore there is an interest for new non thermal technologies.

Food irradiation is a physical method of food processing that involves exposing prepackage food to ionizing energy, this process is sometime called cold pasteurization because the inactivation of 
microorganism is achieved at low temperatures unlike the traditional heat pasteurization (Thalita, et al., 2014) Gamma rays are a short length waves with extensive penetration and lethality and are produced by radioactive, such as cobalt $60(60 \mathrm{co})$ and cesium $137(137 \mathrm{cs})$. Using a low dose of ionizing radiation eliminate or reduce the presences of bacteria, mould and mould spores in meat and meat products prolonged its shelf life (Petwal et al., 2004, Vural et al., 2006, Seri et al., 2012 and Balakrishnan, 2015). The high penetrative ionizing energy have the ability to inactive spoilage and disease causing microorganisms without causing harmful changes to the products, the ionizing energy passes completely through products and their packaging Other food preservation methods such as chemicals and heat treatment kill microorganisms including pathogens. However chemicals leaves residues and heating can change the texture, colour and flavor of the products (Kyzlink, 1990), as well as some enzymes and bacterial spores are thermo-tolerant which require the application of extreme heat treatment that affect nutrition and organoleptic properties of meat (Raso and Barbosa, 2003). Additional advantages of irradiation technology include the possibility of irradiating packed food at its fresh and frozen state, the ionizing energy passes completely through products and their packaging (Sridhar, and Bhat, 2008, Stewart, and Padalia, 2015). Irradiation elemis pathogenic and non pathogenic microorganisms, insects and parasites (Stefanova et al., 2010). Furthermore, irradiation may be considered environment friendly because this method does not consume water and has lower electrical energy demands than other food preservative methods. Irradiation does not increase human exposure to radiation since energy used is not strong enough to cause food to become radioactive (Abid Sarwar et al., 2014). The first international safety recommendation was presented in 1981 whsen a committee of experts considered that the irradiation of food up to an overall average dose of $10 \mathrm{kgy}$ introduces no special nutritional or microbiological problems (FAO/IAEA/ WHO, 1981). The energy from electrons has to target and inactive fungal nucleic acid, this damage occure directly as a results of electron and pheton interaction with DNA and RNA and indirectly through the radio lytic products of water as $\mathrm{H}, \mathrm{OH}$ these free radicals split carbon bonds of macromolecules in the living microorganisms, thereby killing them (Ingram and Farkas 2008, Stewat and Padalia 2015). Energy required to control microorganisms in food varies according to the type of species to be eliminated, according to their population numbers and according to their development state. Other factors such as the composition and moisture content of food, the frozen or fresh state of food, the temperature and level of oxygen present during irradiation, may also influence the resistance of microorganisms to radiation (Farkas, 2006).
Natamycine is a nature antifungal substances produced during the fermentation of the bacterium Streptomyces natalensis (Zeuthen and BoghSorensen, 2003). Natamycin is one of the globally permitted food preservatives to protect a wide variety of food products, its application has a huge potential to extend shelf life and prevent the growth of mould and yeast till the end of storage (El-Diasty et al., 2009). It has been approved as a food additive in over 40 countries and has been considered as a GRAS (generally recognized as safe) product by the Food and Drug Administration (FDA) (El-Daly, 2000and Koontz et al., 2003). Natamycin is a widely used in the food industry for the prevention of mould contamination in meat (Var et al., 2004 Jay et al., 2005 and Welscher et al., 2008), such as Aspergillus carbonarius and ochratoxin production (Medina et al., 2007), and Aspergillus niger, Aspergillus versicolor Penicillium chrysogenum, Penicillium glabrum, Penicillium commune, Penicillium verrucosum (Stark, 2003). Recently, the European Food Safety Authority (EFSA) has published a favorable scientific opinion on the use of natamycin as a food additive (EFSA, 2009). its superiority over other natural antifungal has been attributed to its wide spectrum of antifungal activity at low concentration and it is white tastless and odorless powder so it induce its effect without changing organoleptic characteristics of food products such as cheese, meat and juices (Dzigbordi et al., 2013). Natamycin act by interacts with sterols which present in cellular membrane of fungi and destruct the selective permeable memberane causing leakage and even lysis of cells (Jay, 2000), it slow down the fungal growth for up to six months but it can not completely inhibit it. On the other hand natamycin has no antibacterial activity due to lack of ergosterol compound in the bacterial cell memberane (Delves et al., 2006), this makes it useful for the application on such products which require bacterial processes such as dry sausages (Stark, 2004). It is active at a low concentration $(0.1 \%-0.2 \%)$ and could be applied either by dipping or spraying (Stibing and Oberhaus, 2001, Delves et al., 2006, El-Abbasy, 2007 and Petr, et al., 2010). It is crystalline in structure and melts at temperature $180^{\circ} \mathrm{C}$ and effectively acts at a wide range of $\mathrm{pH}$ from 3 - 9 (Beuchat, 1998). Natamycin concentration of $10 \mathrm{ppm}$ completely inhibited 16 common food spoilage yeasts and moulds by an agar plate method (Klis et al., 1959). Bullerman, (1977) demonstrated that $5 \mathrm{ppm}$ of natamycin prevented growth of all the mould isolates from natural cheese, the majority of which were Penicillium spp, growth of $96 \%$ of the mold isolates was prevented for at least 7 days. Yeasts possess an even greater sensitivity to natamycin than mould. Natamycin appeared to be more effective at inhibiting growth of Aspergillus ochraceus in liquid media than in olive paste (Gourama and Bullerman, 1988). Natamycin has been observed to have an inhibitory effect that is greater on toxin production than on growth for all of the 
toxigenic molds. In studies using laboratory media, a $1 \mathrm{ppm}$ concentration of natamycin inhibited toxin production of aflatoxin $\mathrm{B}_{1}$ by $25 \%$. Natamycin inhibited mycelial growth of Aspergillus. ochraceus by 16 to $52 \%$ at concentrations of 1 to $50 \mathrm{ppm}$, but at $10 \mathrm{ppm}$ ochratoxin production was completely inhibited. The use of natamycin is advantageous for such minced meat as it cannot interfere with the starter bacteria as it has no antibacterial activity (Stark, 2004 and Petr et al., 2010). Natamycin cause defects in the permeability of memberane of the fungi as it interact with sterols, which are present in the cell membrane of the fungal cells and thus it destructs the selective permeable membrane (Jay, 2000 and Adams, and Moss, 2008).

So, the ojective of this review is to highlight the importance of irradiation technology and natamycin to prevent fungal contamination in minced meat and thus enhance the meat quality and increase its shelf life.

\section{MATERIALS AND METHODS}

A total of 60 random samples of fresh minced meat (200gm for each) were purchased from different supermarkets with different sanitation levels in Dakahlia governorates. Samples were divided into 5 equal groups (12 for each). All samples were placed in sealed polyethylene bags and exposed to $10 \mathrm{kGy}$ of gamma radiation for sterilization at the National Center for Radiation Research and Technology (NCRRT), Nasr City, Cairo, Egypt.

Preparation of inoculums: Strains of Candida albicans and Aspergillus niger were obtained from Department of Microbiology, Faculty of Veterinary Medicine, Mansoura University, then prepared to achieved stock culture that was aproximately $10^{9}$ according to Cruickshank et al. (1975) and artificially inoculated into all examined meat samples to give a final concentration $10^{5}$ according to APHA, (1985).

After inoculation, the first group (control group) was not treated, the second, third and fourth groups were irradiated at doses of $(2.5,4.0,6.0 \mathrm{kGy})$ respectively according to Baher, (2010), while the $5^{\text {th }}$ group were treated with $0.1 \%$ natamycin which was applied by spraying according to Petr et al. (2010).

Preparation of samples: All samples were chilled at $4^{\circ} \mathrm{C}$ for 15 days. Total yeast and mould count, were applied at $0,5,10,15$ days of storage as following: twenty five grams of each samples were homogenized with $225 \mathrm{ml}$ of $1 \%$ peptone water in stomacher for 1 minute and serial dilutions were prepared. One $\mathrm{ml}$ of selected dilutions was transferred (in replicates) onto petri dishes and Sabauroud's dextrose agar was poured, the plates were incubated at $30^{\circ} \mathrm{C}$ for $3-5$ days then the count of total mould and yeast was recorded (cfu/gm) according to Cruickshank et al. (1975).

Statistical analysis: The obtained data were analysis using analysis of variance (one way a Anova) SPSS according to Sabine and Brian, (2014).

\section{RESULTS}

The effect of gamma irradiation on total mould and yeast counts in minced meat are presented in table (1) and Fig (1-4) which revealed that non-irradiated samples (control group) had $\left(2.9 \times 10^{5} \pm 8.4 \times 10^{4}\right)$ $\mathrm{cfu} / \mathrm{g}$ of microbial load which increased to (1.9 $\left.\times 10^{6} \pm 6.3 \times 10^{5}\right),\left(2.9 \times 10^{5} \pm 8.4 \times 10^{6}\right) \mathrm{cfu} / \mathrm{g}$ on 5 and 10 days of storage, respectively and became spoiled on 15 day of storage. The total yeast and mould counts were reduced by $2.5 \mathrm{kGy}$ irradiation dose to $\left(1.6 \times 10^{4} \pm 7.8 \times 10^{3}\right), \quad\left(9.9 \times 10^{4} \pm 3.4 \times 10^{4}\right), \quad\left(6.2 \times 10^{5}\right.$ $\pm 2.5 \times 10^{5}$ ) on zero, 5 and 10 days of storage, respectively while samples became reject at 15 day of storage.

Our results revealed that the irradiated samples at 4.0 $\mathrm{kGy}$ showed decrease in total mould and yeast count to $(4.3 \times 10 \pm 2.3 \times 10), \quad(2.7 \times 10 \pm 1.8 \times 10), \quad(4.4 \times 10 \pm$ $2.8 \times 10),\left(8.6 \times 10^{2} \pm 3.2 \times 10^{2}\right) \mathrm{cfu} /$ gon $0,5,10$ and 15 days of storage, respectively. Whereas irradiated samples at $0.6 \mathrm{kGy}$, the mould and yeast count were recorded to non detectable level during 0, 5, 10 days of storage while at 15 day there was a very low mould and yeast count $(9.2 \pm 8.3)$. There was a significant difference between control samples and each radiated samples at 4.0 and $6.0 \mathrm{kGy}$ on 0,5 and 10 days of storage respectively. Also there was a significant difference between doses of 4.0 and $6.0 \mathrm{kGy}$ at 15 days of storage as the control samples were already spoiled before this period and the samples exposed to $6.0 \mathrm{kGy}$ were contained less mould and yeast growth than that exposed to $4.0 \mathrm{kGy}$ radiation dose.

The effect of $0.1 \%$ natamycin on total mould and yeast count was illustrated in table (2) and Fig (5) which showed that, the initial total mould and yeast count in untreated (control) samples were $\left(2.9 \times 10^{5} \pm 8.4 \times 10^{6} \mathrm{cfu} / \mathrm{g}\right)$ increased to $\left(1.9 \times 10^{6}\right.$ $\left.\pm 6.3 \times 10^{5}, 3.0 \times 10^{6} \pm 5.7 \times 10^{5} \mathrm{cfu} / \mathrm{g}\right)$ on 5 and 10 days of storage respectively while became spoiled (rejected) on 15 day of storage. Samples treated with $0.1 \%$ natamycin showed decrease in total mould and yeast count to $\left(8.1 \times 10^{3} \pm 1.4 \times 10^{3}, 3.1 \times 10^{4} \pm 6.8 \times 10^{3}\right.$, $7.9 \times 10^{4} \pm 2.2 \times 10^{4}, 5.0 \times 10^{5} \pm 1.0 \times 10^{5} \mathrm{cfu} / \mathrm{g}$ ) on zero, 5,10 and 15 days of storage respectively. The Statistical analytical results showed that, there was a significant differences between treated samples and untreated (control) samples at 5 and 10 days of storage as well as there was a significant differences between treated samples at 15 day of storage and each treated samples at zero, 5 and 10 days. 
Table 1: Statistical analytical results of total mould and yeast count in non-irradiated (control) and irradiated minced meat ( $\mathrm{N}=12$ for each).

\begin{tabular}{|c|c|c|c|c|c|c|c|c|c|c|c|c|}
\hline & \multicolumn{3}{|c|}{$\begin{array}{c}\text { 0 kGy } \\
\text { Control samples }\end{array}$} & \multicolumn{3}{|c|}{$2.5 \mathrm{kGy}$} & \multicolumn{3}{|c|}{4 kGy } & \multicolumn{3}{|c|}{$6 \mathrm{kGy}$} \\
\hline & Mean & Min. & Max. & Mean & Min. & Max. & Mean & Min. & Max. & Mean & Min. & Max. \\
\hline O day & $\begin{array}{c}2.9 \times 10^{5} \\
\pm \\
8.4 \times 10^{4 \mathrm{~A}} \\
\end{array}$ & $1.4 \times 10^{4}$ & $9.0 \times 10^{5}$ & $\begin{array}{c}1.6 \times 10^{4} \\
\pm \\
7.8 \times 10^{3 \mathrm{a}} \\
\end{array}$ & $1.0 \times 10^{3}$ & $9.0 \times 10^{4}$ & $\begin{array}{c}4.3 \times 10^{1} \\
\pm \\
2.3 \times 10^{1 \mathrm{a}} \\
\end{array}$ & 0 & $2.0 \times 10^{2}$ & 0 & 0 & 0 \\
\hline 5 days & $\begin{array}{c}1.9 \times 10^{6} \\
\pm \\
6.3 \times 10^{5 \mathrm{~B}}\end{array}$ & $1.1 \times 10^{5}$ & $6.0 \times 10^{6}$ & $\begin{array}{c}9.9 \times 10^{4} \\
\pm \\
3.4 \times 10^{4 b}\end{array}$ & $4.5 \times 10^{3}$ & $3.5 \times 10^{5}$ & $\begin{array}{c}2.7 \times 10 \\
\pm \\
1.8 \times 10^{b}\end{array}$ & 0 & $2.0 \times 10^{2}$ & 0 & 0 & 0 \\
\hline $\begin{array}{c}10 \\
\text { days }\end{array}$ & $\begin{array}{c}3.0 \times 10^{6} \\
\pm \\
5.7 \times 10^{5 \mathrm{C}}\end{array}$ & $5.2 \times 10^{5}$ & $7.5 \times 10^{6}$ & $\begin{array}{c}6.2 \times 10^{5} \\
\pm \\
2.5 \times 10^{5 \mathrm{c}}\end{array}$ & $1.5 \times 10^{4}$ & $3.1 \times 10^{6}$ & $\begin{array}{c}4.4 \times 10^{1} \\
\pm \\
2.8 \times 10^{1 \mathrm{c}} \\
\end{array}$ & 0 & $3.2 \times 10^{2}$ & 0 & 0 & 0 \\
\hline $\begin{array}{c}15 \\
\text { days }\end{array}$ & $\mathrm{R}$ & $\mathrm{R}$ & $\mathrm{R}$ & $\mathrm{R}$ & $\mathrm{R}$ & $\mathrm{R}$ & $\begin{array}{c}8.6 \times 10^{2} \\
\pm \\
3.2 \times 10^{2 D}\end{array}$ & $1.1 \times 10^{2}$ & $4.0 \times 10^{3}$ & $\begin{array}{c}9.2 \\
\pm \\
8.3^{\mathrm{d}}\end{array}$ & 0 & $1.0 \times 10^{2}$ \\
\hline
\end{tabular}

$\mathrm{R}=$ rejected. $(\mathrm{A} \& \mathrm{a} / \mathrm{B} \& \mathrm{~b} / \mathrm{C} \& \mathrm{c})=$ There were significant differences between the small and capital litters

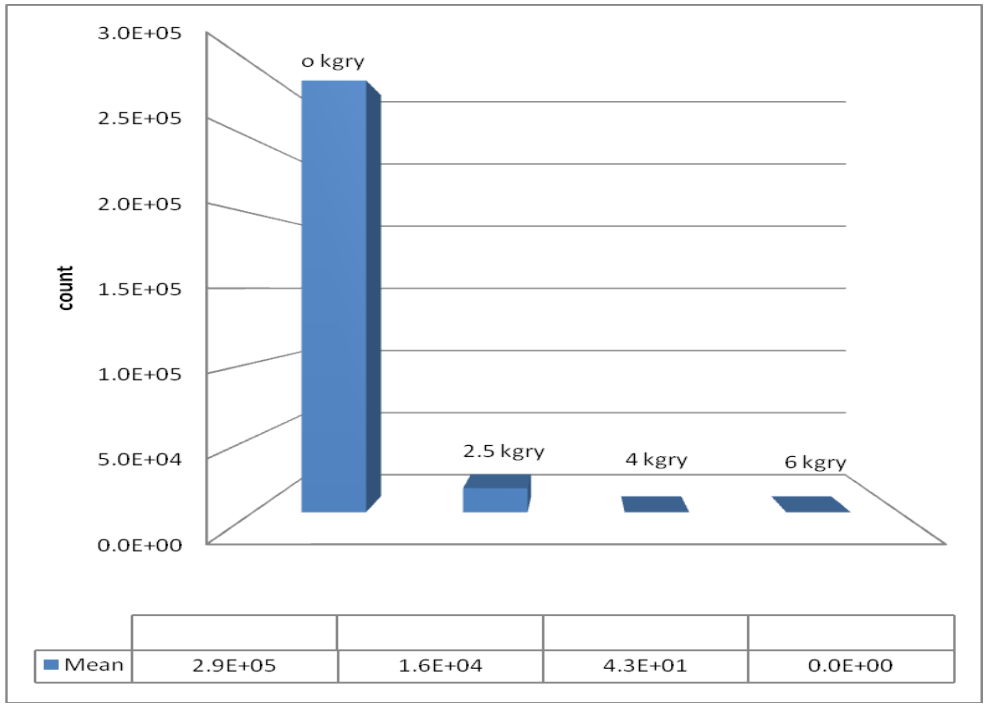

Fig. 1: Statistical analytical results of total mould and yeast count in irradiated and non-irradiated samples on 0 day of storage

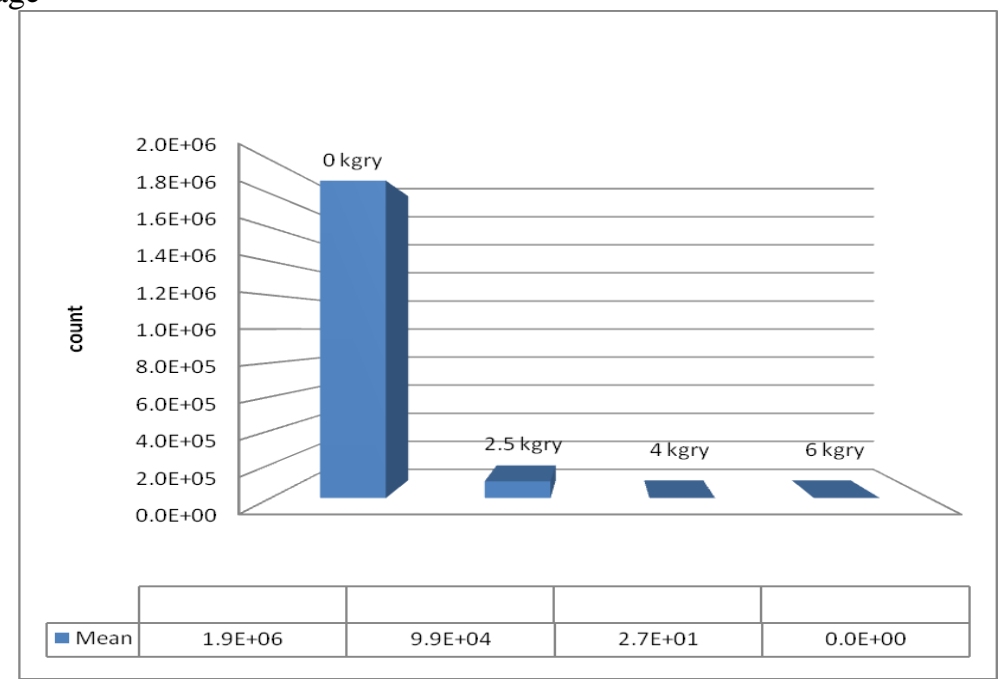

Fig. 2: Statistical analytical results of total mould and yeast count in irradiated and non-irradiated samples on 5 day of storage 


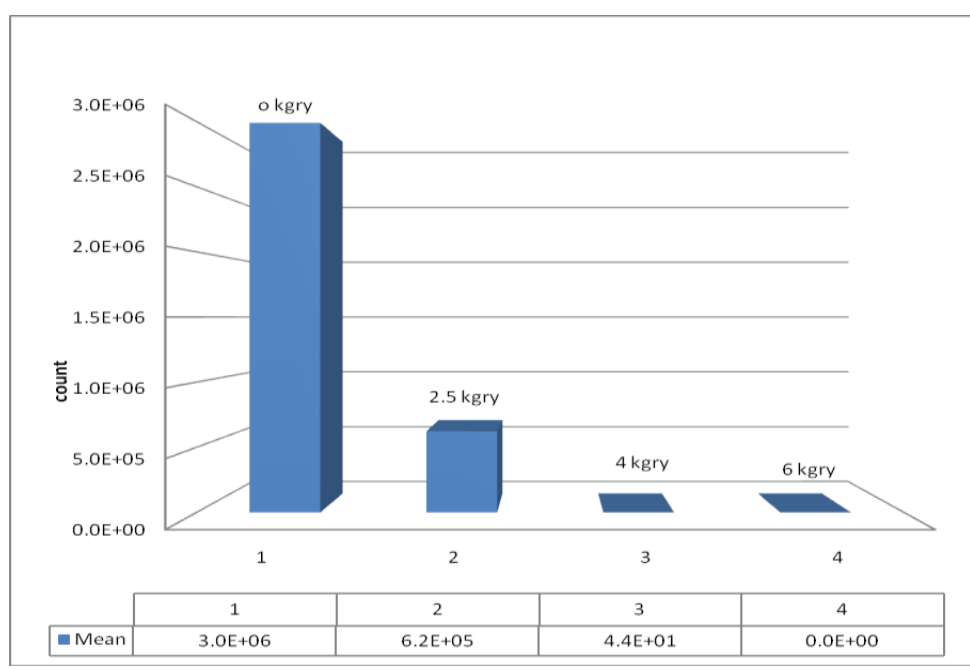

Fig. (3): Statistical analytical results of total mould and yeast count in irradiated and unirradiated samples on 10 day of storage

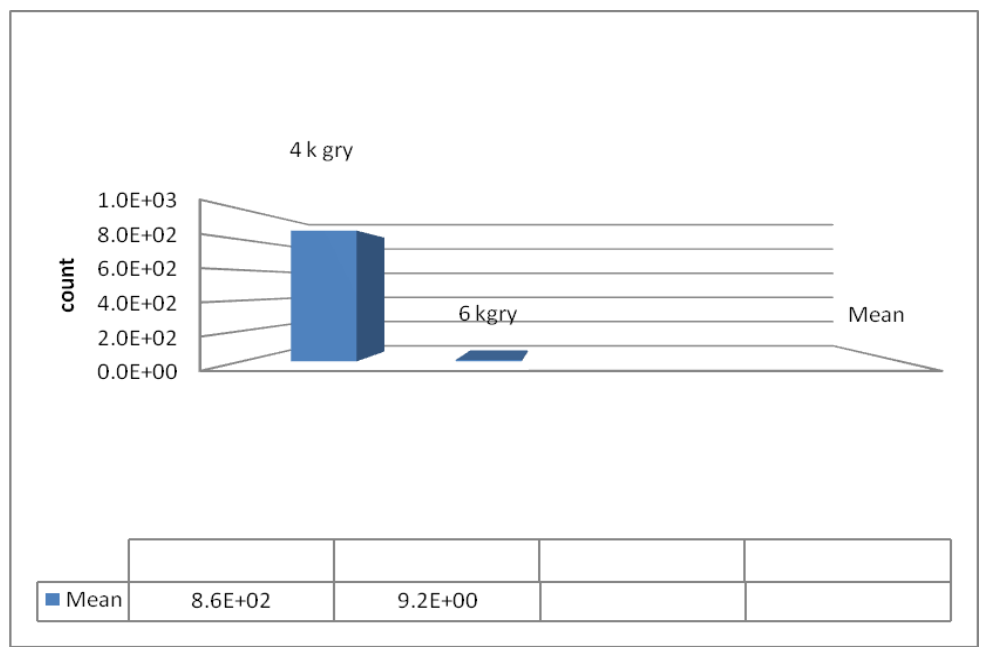

Fig. (4): Statistical analytical results of total mould and yeast count in irradiated and non-irradiated samples on 15 day of storage

Table 2: Statistical analytical results of total mould and yeast count in non treated (control) and treated samples with natamycin $(12=$ of each $)$.

\begin{tabular}{|c|c|c|c|c|c|c|c|c|c|c|c|c|}
\hline & \multicolumn{3}{|c|}{0 day } & \multicolumn{3}{|c|}{ 5days } & \multicolumn{3}{|c|}{10 days } & \multicolumn{3}{|c|}{15 days } \\
\hline & Mean & Min. & Max. & Mean & Min. & Max. & Mean & Min. & Max & Mean & Min. & Max. \\
\hline $\begin{array}{l}\text { Before } \\
\text { treatment }\end{array}$ & $\begin{array}{l}2.9 \times 10^{5} \\
\pm \underset{\mathrm{b}}{8.4 \times I 0^{4}}\end{array}$ & $\begin{array}{c}1.4 \\
\times 10^{4}\end{array}$ & $\begin{array}{c}9.0 \\
\times 10^{5}\end{array}$ & $\begin{array}{c}1.9 \times 10^{6} \\
\pm \\
6.3 \times 10^{5 \mathrm{a}}\end{array}$ & $\begin{array}{c}1.1 \\
\times 10^{5}\end{array}$ & $\begin{array}{c}6.0 \\
\times 10^{6}\end{array}$ & $\begin{array}{c}3.0 \times 10^{6} \\
\pm \\
5.7 \times 10^{5} \mathrm{a}\end{array}$ & $\begin{array}{c}5.2 \\
\times 10^{5}\end{array}$ & $\begin{array}{c}7.5 \\
\times 10^{6}\end{array}$ & $\mathrm{R}$ & $\mathrm{R}$ & $\mathrm{R}$ \\
\hline $\begin{array}{c}\text { After } \\
\text { treatment }\end{array}$ & $\begin{array}{c}8.1 \times 10^{3} \\
\pm \\
1.4 \times 10^{3 \mathrm{~b}}\end{array}$ & $\begin{array}{c}5.4 \\
\times 10^{3}\end{array}$ & $\begin{array}{c}9.0 \\
\times 10^{4}\end{array}$ & $\begin{array}{c}3.1 \times 10^{4} \\
\pm \\
8.6 \times 10^{3 \mathrm{~b}}\end{array}$ & $\begin{array}{c}5.4 \\
\times 10^{3}\end{array}$ & $\begin{array}{c}9.0 \\
\times 10^{4}\end{array}$ & $\begin{array}{c}7.9 \times 10^{4} \\
\pm \\
2.2 \times 10^{4 b}\end{array}$ & $\begin{array}{c}1.0 \\
\times 10^{4}\end{array}$ & $\begin{array}{c}3.0 \\
\times 10^{5}\end{array}$ & $\begin{array}{c}5.0 \times 10^{5} \\
\pm \\
1.0 \times 10^{5 \mathrm{a}}\end{array}$ & $\begin{array}{c}1.0 \\
\times 10^{5}\end{array}$ & $\begin{array}{l}9.9 \\
\times 10 \\
5\end{array}$ \\
\hline
\end{tabular}

$\mathrm{R}=$ rejected each value represented mean \pm S.E. Different letters mean significant difference at $(\mathrm{p} \leq 0.05)$ while the same letters mean non significant difference 


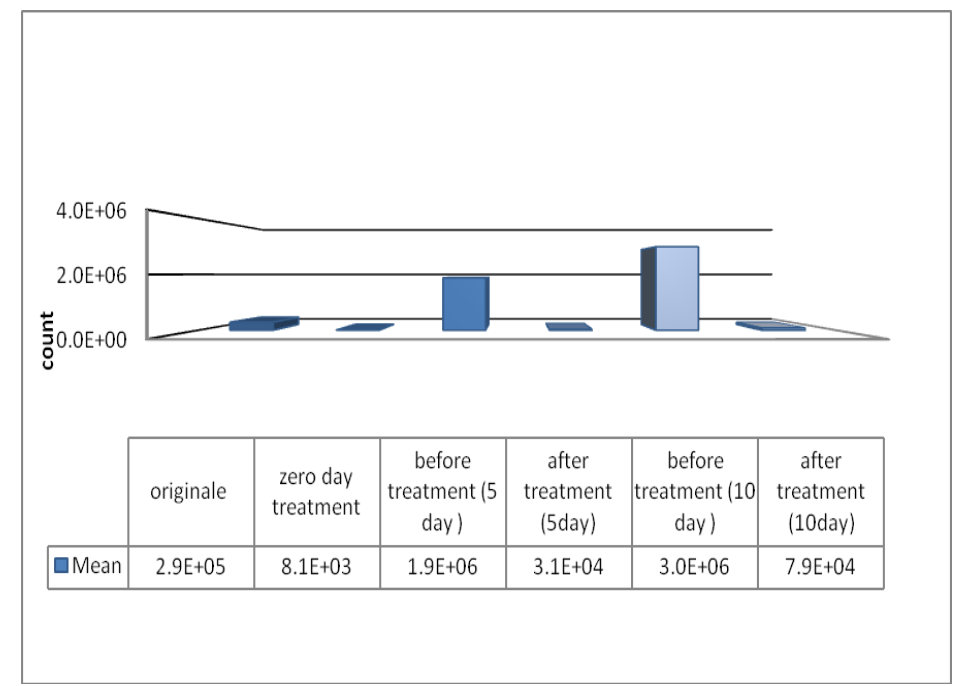

Fig. 5: Statistical analytical results of total mould and yeast count in non treated (control) and treated samples with natamycin

\section{DISCUSSION}

The total yeast and mould counts were reduced by 2.5 kGy irradiation dose on zero, 5 and 10 day of storage, respectively while samples became spoiled at 15 day of storage. The statistical analytical results showed that there was a significant difference $(\mathrm{p}<0.01)$ between non-irradiated (control) samples and each of irradiated samples at 2.5, 4.0,6.0 kGy on zero and 5 day of storage, respectively.

These findings are in agreement with Abid Sarwar et al. (2014) who found that the $2.5 \mathrm{kGy}$ treated poultry and beef samples showed decreasing trend in the development of fungi. Also these findings are agree with Jay, et al., (2005) who reported that low doses of irradiation (less than $3 \mathrm{kGy}$ ) could eliminate pathogens inoculated into ready to eat meat. Also our findings are nearly similar to those obtained by Vural, et al. (2006) who worked on low irradiation doses 1 , 2, $3 \mathrm{kGy}$ in elimination the microorganisms count in raw Turkish meat and found that, the microorganisms count were decreased parallel with the increased doses of radiation. Mould and yeast count were reduced under detectable value by application of 3 $\mathrm{kGy}$. Our results revealed that the samples irradiated at $4.0 \mathrm{kGy}$ showed decrease in total mould and yeast count on $0,5,10$ and 15 days of storage. Whereas samples irradiated at $0.6 \mathrm{kGy}$, the mould and yeast were recorded to non detectable level during $0,5,10$ days of storage while at 15 day there was a very low mould and yeasts count. These findings are disagree with Seri et al. (2012) who mentioned that there was no microbial load in backed ccked chicken sausage irradiated at $3.5 \mathrm{kGy}$ and chilled for 3 month. Chicken burger samples irradiated at $3.5 \mathrm{kGy}$ and later put to chilled storage at $0-3^{\circ} \mathrm{C}$ had initial microbial count $2.1 \times 10^{3} \mathrm{cfu} / \mathrm{g}$, which increases to $1.8 \times 10^{5} \mathrm{cfu} / \mathrm{g}$ after 2 weeks and became spoiled after 1 months. He added the irradiated products with doses of 5.5 and $10.0 \mathrm{kGy}$ were free from microbial load including from mould and yeast at chilled storage 3 months. Also our results are nearly agree with Abid Sarwar et al. (2014) who uses of gamma irradiation to eliminate mould and yeast count from poultry and beef samples and found that total mould and yeast count were reduced under detectable value after application of $5 \mathrm{kGy}$ irradiated dose. From our results it was clear that treatment of minced meat with low doses of ionizing radiation $(2.5,4.0,6.0) \mathrm{kGy}$ are considered as an effective procedure for meat decontamination and shelf life extension as the total mould and yeast counts were slowly and gradually increased in all irradiated samples during storage period in comparison with the highly increased in unirradiated (control) samples. Irradiation extend the shelf life of food without causing harmful changes in the texture, colour, and flavor of the products (Stefanova et al., 2010, Petwal et al., 2004, and Sofos, 2009). The killing effect of irradiation is attributed to breaking of chemical bond of DNA orto formation of highly reactive redical which split carbon bond of macromolecules in living microorganism so, killing them (Ingram and Farkas 2008).

Samples treated with $0.1 \%$ natamycin showed decrease in total mould and yeast count at zero, 5, 10and 15 days of storage. These results are in agreement with El-Tawab, (2014) who reported that natamycin $(0.1 \%)$ had a higher inhibitory effect than potassium sorbate $(2 \%)$ as total mould count (log $\mathrm{cfu} / \mathrm{g}$ ) was reduced from 4.69 in control group to 2.96 and 3.39 in natamycin and potassium sorbate treated groups respectively. In addition our results agreed with Petr et al. (2010) who reported that natamycin $(0.1$ and $0.2 \%)$ proved to be the most efficient mould suppression on the surface of dry sausage (both heated and fermented). Also our results in accordance with El-Abbasy, (2007) who stated that the 
application of 0.1 natamycin on quail carcass reduced the total yeast and mould count. (Hassan and El Lawandy, 2006) found that natamycin (50ppm) reduced the total mould count $(\log \mathrm{cfu} / \mathrm{g})$ from 3.44 in ordinary formulated sausage to 2.28 in natamycin treated sausage and from 3.10 in ordinary formulated Frankfurt to 1.96 in natamycin treated frankfurters. Salem et al. (2016) reported that natamycin 300 ppm proved to be efficient in suppression of A. niger growth in minced meat so, the use of natamycin (300ppm) is recommrnded to improve safety of meat products.

\section{CONCLUSION}

We can concluded that gamma irradiation at low doses $(2.5,4.0,6.0) \mathrm{kGy}$ are sufficient in reduction of total mould and yeast count in fresh minced meat chilled at $4 \mathrm{C}^{\circ}$ This reduction was proportional with the irradiation doses. The irradiated samples at 2.5 kGy spoiled at 10 day of storage while samples irradiated at $6.0 \mathrm{kGy}$ contain less number of microorganisms than that exposed to $4.0 \mathrm{kGy}$ on 15 day of storage, as during storage, the count of examined microorganisms increased but the rate of increasing was slower as the irradiation dose increased. As well as natamycin $0.1 \%$ are efficient in reduction of total mould and yeast count at $0,5,10$ and 15 day of storage. So the use of irradiation and natamycin, are recommended to improve safety of meat and meat products.

\section{REFERENCES}

Abid, S.; Sami U.; Fahim, U.; Misal, KH. and Waheed, $U$. (2014): Effect of gamma irradiation on microbial quality of red and poultry meat sold and processed in Pesh Ware, Pakistan. European Academic Research (1) Issue 12/2014. 5815-5861.

Adams, R.A. and Moss, M.O. (2008): Food Microbiology. RSC Publishing, Cambridge, UK.

American Puplic Health Association (APHA) (1985): Compendium of food, $2^{\text {nd }}$ Ed., American puplic Health Association, Washington, D.C.

Anandaraja, S.; Kothari, S. and Nath, R. (2006): Fungal ball blocking the aortic vave. Echocardiography, 2: 164.

Baher, M. Weam (2010): Effect of irradiation on microbial and sensory characters of artificially inoculated fresh meat. Thesis of M.V.Sc. Department of Food Control (meat hygiene). Faculty of Vet. Med. Zagazig University.

Balakrishnan, S. (2015): Radiation Processing of Food, Press Information Bureau, Government of India Feature. Retrieved on 02 Oct., 2015.
Beuchat, L.R. (1998): Effects of potassium sorbate and sodium benzoate on inactivating moulds heated in broth containing sodium chloride and sucrose. J. Foods Protect. 62(10): 765-769.

Bullerman, L.B. (1977): Incidence and control of mycotoxin producing molds in domestic and imported cheeses. Annales de la Nutrition et de l'Alimentation. 31: 435-446.

Cruickshank, R.; Duguid, J.P.; marino, B.P. and Swain, R.H.A. (1975): Medical microbiology $12^{\text {th }}$ Ed. Vol., Chuurchill Livingston. London and New York.

Dahama, K.; Chakraboty, S.; KKumar, A.V. and Singh, S.D. (2013): Fungal/Mycotic Diseases of Poultry diagnosis, Treatment and Control: A Review. Pakitan J. of Biological Sciences 16(23): 1626-1640

Delves, B.J.; Thomas, L.V. and Williams, G. (2006): Natamycin as antimycotic preservative on cheese and fermented sausages. Food Australia, 58: 19-21.

Dzigbordi, B.; Adubofuor, J. and Faustina Dufie, W.M. (2013): The effects of different concentrations of natamycin and the point of addition on some physicochemical and microbial properties of vanilla-flavoured yoghurt under refrigerated condition. International Food Research Journal 20(6): 3287-3292.

EFSA (European Food Safety Authority (2009): Scientific opinion on the use of natamycin (E 235) as a food additive. EFSA Journal 7, 1412.

El-Abbasy, M.TH. (2007): Mycological aspect. The radiation process was ects of quail carcass with a trial to improve their sanitary 1status. M.V. Sc. Thesis, Fac. Vet. Med., Zagazig University. Developments and future outlook for postslaughter food safety. J. Ani. Sci. (87) 2448-2457.

El- Daly, A.E. (2000): Fundamentals of meat Hygien. $1^{\text {st }}$ Ed., Egy

El-Diasty, M.E.; El-Kaseh, R.M. and Salem, R.M. (2009): The effect of natamycin on keeping quality and organoleptic characters of yoghurt. Arab Journal of Biotechnology 12(1): 41-48.

El-Tawab, M.M. (2014): studies on mycotoxins in some meat products M.V. Sc. (Meat Hygien), Fac.Vet. Med., Banha Unvi. Egypt.

FAO/IAEA/WHO (1981): Wholesomeness of irradiated food. Technical Report Series 659. Geneva. Switzerland Joint FAO/IAEA/WHO Expert Committee.

Farkas, J. (2006): Irradiation for better foods.Trends Food SciTechnol 17:148-52.

Farkasm, J. (1989): Irradiation as method for decontaminating food. Int. J. Food Mic. 44, 189-204. 
Gourama, Hand Bullerman, LB. (1988): Effects of potassium sorbate and natamycin on growth and penicillic acid production by Aspergillus ochraceus. Journal of Food Protection. 51 (2): 139-144, 155

Hassan M.A. Hannan and El-Lawandy, M.T. (2006): Control of mycological hazards associated with consumption of some meat products with special reference to mycotoxins. Zag. Vet. J. (ISSN,1110-1458), 34 (1): 12-18.

Ingram, M. and Farkas, J. (2008): Microbiology of food pasteurized by ionized radiation. Acta Aliment 22(5): 775-777.

Jay, J.M. (2000): Modern Food Microbiology $.6^{\text {th }}$ Ed. Springer-Verlage, Berlin: 272-273.

Jay, J.M.; Loessner, M.J. and Golden, D.A. (2005): Modern food microbiology 7th edition. Springer Science- Business Media. New York, NY. pp: 328.

Klis, JB.; Witter, LD. and Ordal, ZJ. (1959): The effect of several antifungal antibiotics on the growth of common food spoilage fungi. Food Technology. 13: 124-128. K

Koontz, J.; Marcy, J.; Barbeau, W. and Duncan, S. (2003): Stability of natamycin and its cyclodextrin inclusion complexes in aqueous solution. Journal of Agricultural and Food Chemistry, 51(24), 7111-7114.

Kyzlink, V. (1990): Principles of food preservation. Dev. Food Sci. 22, 337-355.

Ma, J.E.; Yun, EY.; Kim Y.E. and Hwang Y.S. (2011): Endobronchial aspergilloma :Report of 10 casesc and literature review. Yonsi Med. J. 52: 787-792

Medina, A.; Jimenez, M.; Mateo, R. and Magan, N. (2007): Efficacy of natamycin for control of growth and ochratoxin A production by Aspergillus carbonarius strains under different environmental conditions. Journal of Applied Microbiology 103: 2234-2239. Mehanna, N. M., Sahel, T.

Nurzhan, K. (2015): Killer yeast or Survival Instinct. Control (Apple) F. For genetics May 18(9)47,101.

Petr, P.; Bo-Anne R.; Anna L. and Ladislav, S. (2010): Suppression of mould growth on dry susages Czech J. Food Sci. 28(4). 258-263.

Petwal, V. and Svodobova, V.; Batonicek, B. Rosmus, J. and Camra, M. (2004): Radiation processing of food products with $5 \mathrm{mv}$ Bremsstrah lung Xray. Ann. Conf. Indian Nul., Sco, Nucl., Tech., Societal needs. Mumbai, India, 15-17.

Raso, J. and Barbosa Canovas, G.V. (2003): No thermal preservation of food using combined processing techniques. Crit. Rev. Food Sci. Nutr., 43: 265

Sabin, L. and Brian, S.E. (2014): A hand book of statistical analysis using CHAPMAN and HALL/CRC. A Press User manual SPSS. INC. /SPSS.Ver 20.
Salem, M. Amani.; Amin A. Reham; Kater, F. Dalia and Shokr, A. Loaloa (2016): Antifungal effect of some chemical preservatives on Aspergillus niger in minced beef meat. Banha Vet. Med. J. 30 (1) 295-301

Seri, C. and Mohd, Y. (2006): Development of shelf Stable meat sausages using gamma irradiation. Malaysian Institute for Nuclear Technology Research MINT, brangi (Malaysia) MINT R and D 2006 Seminar: Compilation of papers Sep. 2006, 679: 264-268.

Seri, C.M.; Yusef, Foziah A.; Salahbiah, A.; Mariani, D. and Muhamad L.J. (2012): Radiation decontamination of ready - to eat meat products. International conference on Agricultural and Food Engineering for Life (Cafei 2012).

Singh, S.D.; Tiwari, R. and Dhama, K. (2012): Mycotoxins and Mycotoxicosis impact on poultry health and production: An overview. Poult. Punch, 28: 35-52.

Sirion, P.H. and Gary, P. (2005): Rapid identification of yeast isolates using BD BBL Chrom agar candida. As presrnted at $105^{\text {th }}$ General Meeting of the American Socity Microbiology, 2005. LR894.

Sofos, J.N. (1990): Developments and future outlook for postslaughter food safety. J. Ain. Sci. (87) 2448-2457.

Soriano, J.M.; Rixo, H.; Molto, J.C. and Manes, J. (2000): Assessment of the microbiological quality and wash treatments of lettuce served in University restaurant. Inter. J. Food Microbiol. 58: 123-128.

Sridhar, KR. and Bhat, R. (2008): Electron beam irradiation an emergining technology for fungal decontamination of food and agricultural commodities. In: Novel Techniques and Ideas in Mycology (eds.K.R. Sridhar, F. and K. H. Hyde). Fungal Diversity x Research Series 20: 271-303.

Stark, J. (2003): Natamycin: an effective fungicide forfood and beverages. In: Natural Antimicrobials for the Minimal Processing of Foods. (Roller, S. Ed.). Wood head Publishing Limited, Cambridge, UK. pp: User manual SPSS. INC 82-97.

Stark, J. (2004): Permitted preservatives - natamycin. In: Robinson K.K., Batt C.A.: Encyclopedia of Food Microbiology. Academic Press, London: 1776-12781

Stefanova, R.; Vasilev, NV. and Spassov, SL. (2010): Irradiation of food current legislation framework, and detection of irradiated foods. Food Anal Method 3: 225-52.

Stewart, M. and Padalia, U. (2015): Electron Beam irradiation -An environmentally safe method of fungal decontamination and food preservation. Int J. of Life Sciences, Special Issue, A5. ISSN: 2320 -7817. 
Stiebing, A. and Oberhaus, T.J. (2001): Natamycinprevention of mould growth in raw sausages Fleischwirtschaft, 81: 79 -100.

Thalita, C.; Armando, V. and Luis, A. (2014): Irradiation for mold and mycotoxincontrol. Comprehensive Reviews in Food Science and Food Safety .Vol.13, 1048-1061.

Var, I.; Sahan, N.; Kabak, B. and Golge, O. (2004): The effect of natamycin on the shelf life of yoghurt. Archiv Fur Lebensmittel hygiene 55(1): 7-9.

Varga, J.; Rigo, K. and Teren, J. (2005): Degradation of ochratoxin A by Aspergillus species. Int. J. Food Microbiol.59, 1-7
Vural, A.; Aksu, H. and Erkan, M. (2006): Low dose radiation as a measure to improve microbiological quality of Turkish raw meatball (cig kofte), Int J. Food Sci. Technol., 41, pp.1105-1107.

Welscher, Y.M.; Napel, H.H.; Balagué, M.M.; Souza, C.M.; Riezman, H. and Kruijff, B. (2008): Natamycin blocks fungal growth by binding specifically to ergosterol without permeabilizing the membrane. Journa of Biological Chemistry 283(10): 6393-6401.

Zeuthen, P. and Bogh-Sorensen, I. (2003): Food preservation Techniques. Woodhead Publishing, Cambridge: 15-16.

\title{
تأثير التثعيع والنتاميسين على ازالة التلوث بالفطريات من اللحوم المفرومة المحقونة معمليا \\ دعاء أحدد حسين المطري ، وئام محدد باهر ، نشوى محد زكى
}

Email: doaaelmatary@yahoo.com Assiut University web-site: www.aun.edu.eg

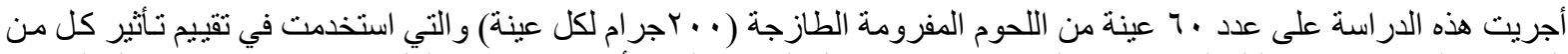

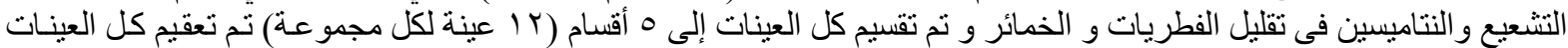

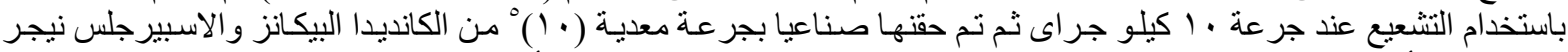

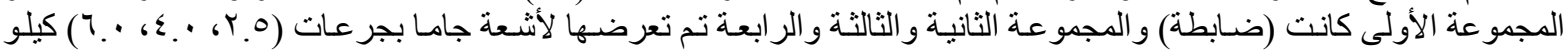

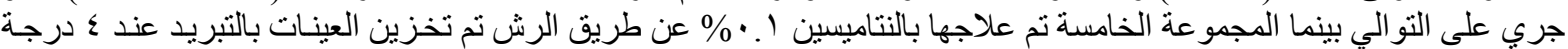

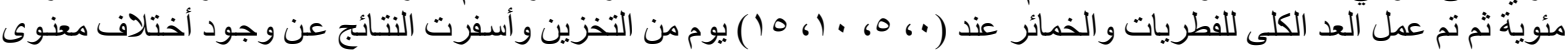

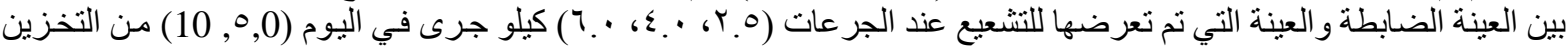

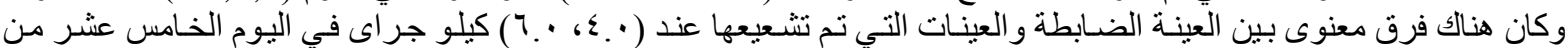

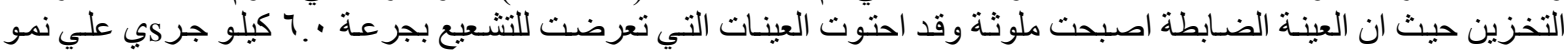

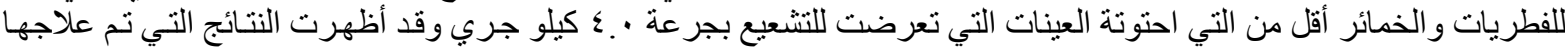

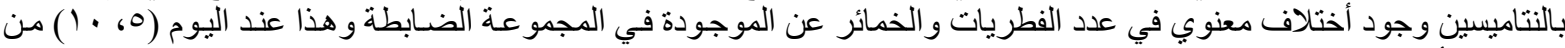

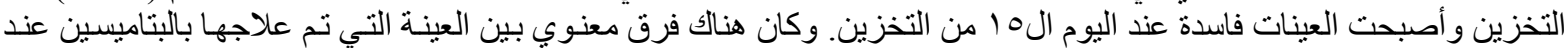

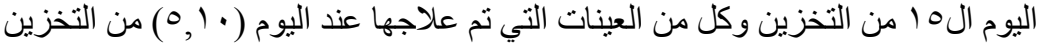

